Animating Film Theory 



\section{Animating Film Theory}

Karen Beckman, editor 
(C) 2014 Duke University Press

All rights reserved

Printed in the United States of America on acid-

free paper $\circledast$

Typeset in Chaparral Pro by Tseng Information

Systems, Inc.

Library of Congress Cataloging-in-Publication Data

Animating film theory / Karen Beckman, editor.

pages $\mathrm{cm}$

Includes bibliographical references and index.

ISBN 978-o-8223-5640-o (cloth : alk. paper)

ISBN 978-o-8223-5652-3 (pbk. : alk. paper)

1. Animated films - History and criticism.

2. Animated films - Social aspects.

3. Animation (Cinematography) I. Beckman,

Karen Redrobe

NC1765.A535 2014

$791.43^{\prime} 34-$ dc23 2013026435

"Film as Experiment of Animation-Are Films

Experiments on Human Beings?” (c) Gertrud Koch. 
In memory of Ruth Wright (1917-2012) 
